Hubert ORDON SDS

(Lublin, KUL)

\title{
ARARAT I ARMENIA NA KARTACH BIBLII
}

Jubileusz 1700-lecia oficjalnego przyjęcia chrześcijaństwa przez Armenię i podniesienia go do rangi religii państwowej przez ówczesnego króla Tyrydatesa III, inspiruje do bliższego zainteresowania się wielowiekową historią, wspaniałym, ale i tragicznym losem, a nadto bogatą kulturą tego fascynującego kraju i jego mieszkańców. Wzmianki o nim pojawiają się w wielu dokumentach starożytnych autorów, w tym także kilka razy w Biblii. One to właśnie będą przedmiotem poniższego omówienia, co z uwagi na ich czas pochodzenia ma swoje szczególne znaczenie.

Po raz pierwszy w Starym Testamencie nazwa Ararat występuje przy okazji potopu $(\mathrm{Rdz} 8,4)$, wydarzenia należącego do okresu prehistorycznego, natomiast w okresie historycznym pojawia się w związku z zabójstwem Sennacheryba, władcy Asyrii (2Krl 19, 37; Iz 37, 38; por. Tb 1, 21). Do powyższych tekstów trzeba jeszcze dodać proroctwo Jr 51, 27 z VI wieku, gdzie wzmianka o Araracie pojawia się w zapowiedzi zburzenia Babilonu.

1. Śmierć Sennacheryba ( $2 \mathrm{Krl} 19$, 37; Iz 37, 38). Po częściowo udanej wyprawie do Judei władca potężnej Asyrii, odstępując od oblężenia Jerozolimy, pospiesznie powrócił do swej stolicy Niniwy. Przyczyną tego faktu upatrują opisy biblijne w szczególnej opiece Bożej nad świętym miastem i pobożnym królem Ezechiaszem, której dowodem była gwałtowna śmierć licznych zastępów wrogiego wojska (2Krl 19, 32-35; Iz 37, 33-36). Niezależnie od tego, na zaskakująco nagły odwrót mogły również wpłynąć niepokojące wieści, jakie dotarły do Sennacheryba ze stolicy (2Krl 19, 7; Iz 37, 7). I właśnie w Niniwie w 681 r. podczas składania ofiary w świątyni boga Nisroka dosięgły go miecze morderców, którymi okazali się dwaj synowie królewscy Adramelek i Sereser. W obawie przed konsekwencjami ojcobójcy, jak informuje Biblia, uciekli do kraju Ararat.

Występująca w tekście hebrajskim nazwa Ararat pochodzi od wcześniejszej Urartu, spotykanej w dokumentach asyryjskich, babilońskich i perskich. Początkowo oznaczała ona wyżynne i górzyste terytorium położone na północ od Asyrii wokół jeziora Wan, w środkowym biegu rzeki Arakses, a następnie 
powstałe tam w IX w. przed Chr. państwo. Utworzone z połączenia plemion hurryckich Urartu doszło do rozkwitu i politycznej świetności w następnych dwu wiekach. Wtedy też rozszerzyło ono swoje granice na północy aż po rzekę Kurę i pas gór nad Morzem Czarnym, na zachodzie sięgnęło górnego biegu Tygrysu i Eufratu, zaś na południowym wschodzie zagarnęło tereny wokół jeziora Urmia. Kres temu potężnemu kiedyś organizmowi państwowemu położyli ok. 590 r. przed Chr. Medowie i Scyci.

Spustoszoną i wyludnioną krainą zaczęły z czasem przyciągać, a od połowy VI w. przed Chr. stopniowo zasiedlać, plemiona indoeuropejskich Hajów. Te szczepy zostały nazwane przez Persów Armeńczykami, co w następstwie pociągnęło za sobą określanie zajętych przez nich terenów - Armenią. W ten sposób nowa nazwa Armenia, która zastąpiła wcześniejszą Urartu-Ararat, weszła na stałe do historiografii. Na kartach Biblii pojawia się ona tylko jeden raz, mianowicie w greckim tłumaczeniu LXX tekstu Iz 37, 38.

2. Zapowiedź upadku Babilonu (Jr 51, 27). W ostatnich proroctwach skierowanych przeciw Babilonowi (Jr 50-51) - stolicy imperium, które w 586 r. przed Chr. zniszczyło królestwo Judy i obróciło w ruinę Jerozolimę wraz ze świątynią Jeremiasz obwieszcza z kolei jego unicestwienie. Będzie to dzieło samego Jahwe, który wezwie i poprowadzi do zwycięskiej walki ze stolicą Babilonii wiele państw i narodów, m.in. królestwa Ararat, Minni i Aszkenaz. Interesującą nas wzmiankę o nieistniejącym już wówczas królestwie Urartu, można wyjaśnić jedynie trwającą nadal tradycją o jego potędze, świetności, znacznym wpływie politycznym i militarnej ekspansji. Tylko bowiem dzięki takiemu organizmowi państwowemu było możliwe całkowite pokonanie silnej Babilonii.

3. Arka Noego a Ararat $(\mathrm{Rdz} 8,4)$. Tak hebrajski jak i grecki tekst biblijny o potopie podają, że krążąca po wodach arka osiadła na górach Ararat. Autorowi chodziło tu bez wątpienia o wyżynno-górzystą krainę wokół jeziora Wan, o której była mowa powyżej. Tam bowiem, w jego przekonaniu, leżały najwyższe wzniesienia świata. Nieprecyzyjne jednak rozumienie wypowiedzi Rdz 8, 4 sprawiło, że miejsce zatrzymania korabia zaczęto utożsamiać z Araratem wyniosłym masywem górskim leżącym we wschodniej Anatolii na terytorium starożytnej Armenii. Sytuację ułatwił fakt, że pierwotną nazwę kraju, a następnie królestwa Urartu, przeniesiono z czasem na ten masyw.

Ararat jest wygasłym wulkanem wydatnie dominującym nad całą okolica, pokrytym w górnych partiach lodowcem i wiecznym śniegiem. Najwyższy z jego szczytów zwany Wielkim Araratem osiąga wysokość 5165 metrów, kolejny zaś określany jako Mały Ararat dochodzi do 3915 metrów. Osnuty licznymi legendami i traktowany przez Ormian jako ich święta góra, był od dawna przedmiotem nie tylko głębokiej fascynacji, ale i licznych wypraw eksploracyjnych.

$\mathrm{Na}$ zainteresowanie się Araratem niewątpliwy wpływ miała niewłaściwa interpretacja tekstu $\mathrm{Rdz} 8$, 4, ale także obiegające od czasu do czasu świat 
wiadomości o znalezieniu drewnianych fragmentów jakiejś wielkiej łodzi, czy też dostrzeżeniu w wyniku stopienia po długim i upalnym lecie lodów oraz śniegu dziwnego obiektu o kształtach ogromnego statku. W związku z tym można było zaobserwować, zwłaszcza od połowu XIX wieku, znaczną intensyfikację ekspedycji bardziej czy mniej naukowych w poszukiwaniu szczątków arki. Wyprawy te są kontynuowane po dzień dzisiejszy, a do znanych współczesnych badaczy należą: Fernand Navarra, Ron Wyatt, John D. Morris, John Baumgardner.

Nie ulega wprawdzie wątpliwości istnienie w odległości ok. $30 \mathrm{~km}$ poniżej Wielkiego Araratu jakiegoś dziwnego obiektu przypominającego ogromną łódź, to jednak zebrany dotąd materiał dokumentacyjny prowadzi do wniosku, że mamy tu do czynienia z osobliwą, ale tylko formacją geologiczną. Do takiego rezultatu doprowadziły przeprowadzone zwłaszcza przez J. Baumgardnera pomiary magnetometryczne i sejsmologiczne, badania radarem i głębokie wiercenia. W miejscach poszukiwań nie znaleziono również dotąd ani kopalnego drewna ani skamieniałej przez wieki trzciny, co w tym przypadku miałoby swoje znaczenie.

\section{LITERATURA:}

A. Parrot, Déluge et Arche de Noé, Paris 1952; F. Navarra, J'ai trouvé l'Arche de Noé, Paris 1956; B.B. Piotrowskij, Vanskoe carstwo (Urartu), Moskwa 1959; M. Riemenschneider, Das Reich am Ararat, Heidelberg 1966; K.H. Bernhardt, Die Umwelt des Alten Testaments, Bd. 1: Die Quellen und ihre Erforschung, 2. Aufl., Berlin 1968; J. Zabłocka, Historia Bliskiego Wschodu w starożytności, Wrocław 1982; G. Báez-Camargo, Archaeological Commentary on the Bible, Garden City NY 1986; Das Reich Urartu, ed. V. Haas, Konstanz 1986; J. Bright, Historia Izraela, tłum. J. Radożycki, Warszawa 1994; P.K. Mc Carter i in., Starożytny Izrael. Od czasów Abrahama do zburzenia Jerozolimy przez Rzymian, tłum. W. Chrostowski, Warszawa 1994; L.R. Bailey, Wood from „Mount Ararat” Noah's Ark?, „Biblical Archeologist" 40 (1997) 137-146.

\section{ARARAT UND ARMENIEN IN DER BIBEL}

\section{(Zusammenfassung)}

Nur paar Mal kommt der Name Ararat im hebräischen AT vor (Gen 8, 4; 2 Kön 19, 37; Tob 1, 21; Jes 37, 38; Jer 51, 27). Er entspricht dem assyrischen Urartu, womit ursprünglich das Land um See Van und nachträglich das dort enstandene Reich benannt wurden. Der Name Armenien dagegen erscheint allein im griechischen Text von Jes 37, 38 (LXX). Der Artikel bespricht die obengenannten biblischen Stellen und versucht einen Überblick über den heutigen Stand der Forschungen auf dem Berg Ararat und deren Ergebnisse zu geben. 